Reprod. Nutr. Dévelop., 1985, 25 (1 B), 303-319.

\title{
Fatty acid oxidation and ketogenesis during development
}

\author{
J. GIRARD, P. H. DUÉE, P. FERRÉ. J. P. PÉGORIER, F. ESCRIVA, \\ J. F. DECAUX
}

Centre de Recherches sur la Nutrition, C.N.R.S., 9, rue Jules-Hetzel, 92190 Meudon-Bellevue, France.

Summary. Fatty acids are the preferred oxidative substrates of the heart, skeletal muscles, kidney cortex and liver in adult mammals. They are supplied to these tissues either as nonesterified fatty acids (NEFA), or as triglycerides after hydrolysis by lipoprotein lipase. During fetal life, tissue capacity to oxidize NEFA is very low, even in species in which the placental transfer of NEFA and carnitine is high. At birth, the ability to oxidize NEFA from endogenous sources or from milk (a high-fat diet) develops rapidly in various tissues and remains very high throughout the suckling period. Ketogenesis appears in the liver by 6 to $12 \mathrm{hrs}$ after birth, and the ketone bodies are used as oxidative fuels by various tissues during the suckling period. At the time of weaning, the transition from a high-fat to a highcarbohydrate diet is attended by a progressive decrease in the ketogenic capacity of the liver, whereas other tissues (skeletal muscle, heart, kidney) maintain a high capacity for NEFA oxidation. The nutritional and hormonal factors involved in changes in fatty acid oxidation during development are discussed.

\section{Introduction.}

In adult mammals, fatty acids are the major oxidative fuel of the body in the post-absorptive period and during fasting, cold exposure and the consumption of a high-fat diet. The principal organs responsible for fatty acid oxidation are the heart, skeletal muscles, liver and kidney cortex. Fatty acids are supplied to these tissues from the blood as non-esterified fatty acids (NEFA) bound to albumin or as triglycerides in chylomicrons and very-low-density lipoproteins. Prior to their utilization in extra-hepatic tissues, the triglycerides are hydrolysed to NEFA by lipoprotein lipase. Although quantitative information on the direct contribution of triglyceride fatty acids to oxidative metabolism is lacking in adults, it is generally accepted that the bulk of the fatty acids oxidized reach the tissues in the form of NEFA (Robinson, 1969 ; Krebs, 1972).

Before considering the cellular aspects of fatty acid oxidation during development, it would be useful to review briefly the pathway involved in fatty acid oxidation in adult tissues. The mechanisms involved in the uptake of NEFA by the cells are unclear but they may depend upon specific transport systems. 
However, it appears that this process is energy-independent and functions to maintain an equilibrium between the plasma and the cellular pools of NEFA (Spector, 1971). Once inside the cell, NEFA are bound to fatty acid binding protein (FABP) (Ockner et al., 1972) which delivers long-chain fatty acids to their sites of activation to fatty acyl-CoA (FACoA) by acyl-CoA synthetases (fig. 1). Fatty acids with a chain length of more than 12 carbons are activated to their

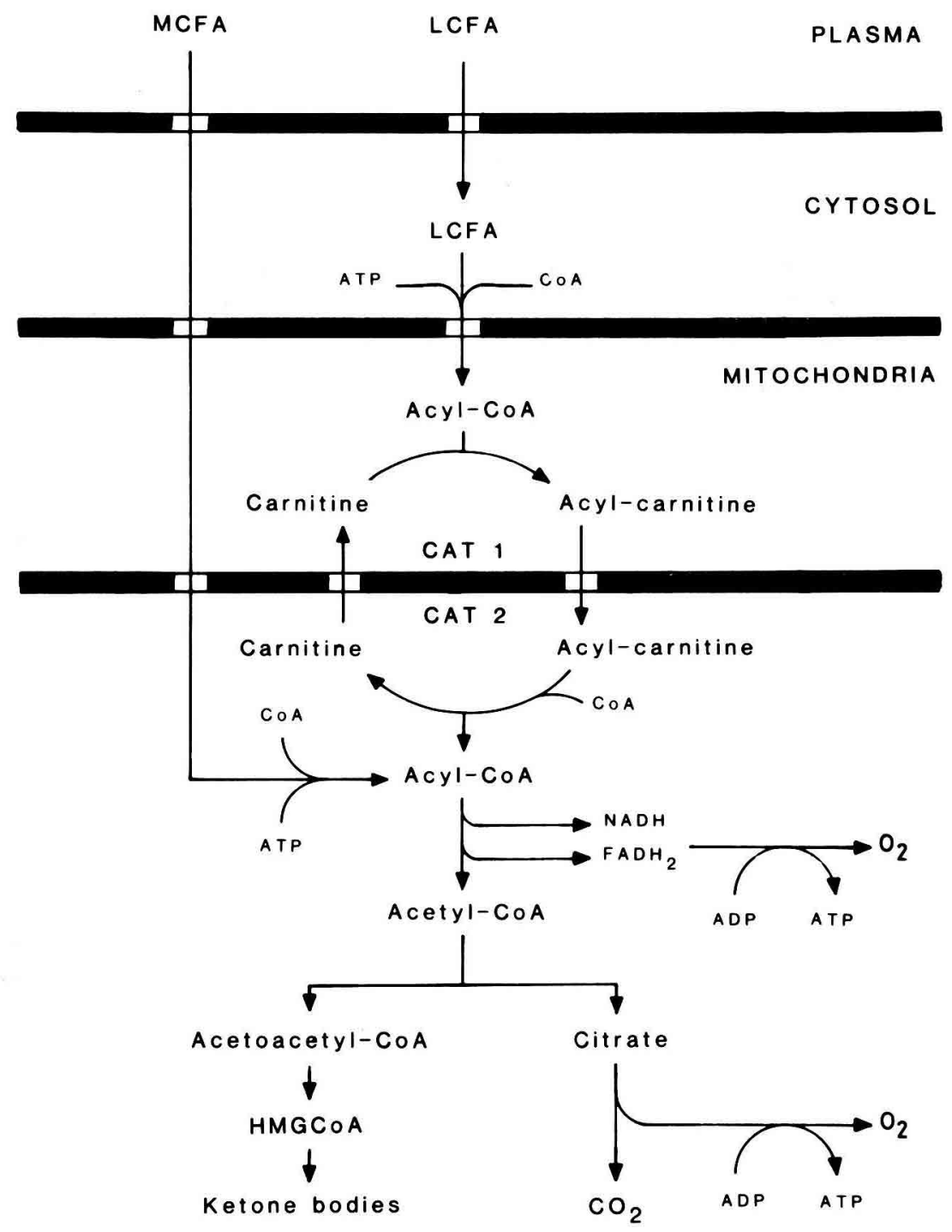

FIG. 1. - Pathway of fatty acid catabolism. LCFA : long-chain fatty acids ; MCFA : medium-chain fatty acids ; CAT I and CAT II : carnitine acyltransferase I and II. The acetyl-CoA can be oriented towards $\mathrm{CO}_{2}$ or ketone body synthesis. See text for further details. 
corresponding acyl-CoA in the cytosol by acyl-CoA synthetases located on the microsomes and the outer mitochondrial membrane (Bremer and Osmundsen, 1984). The microsomal enzyme could be involved in providing acyl-CoA for esterification, whereas the mitochondrial enzyme could provide acyl-CoA for oxidation. It is not known whether these enzymes share a single pool of long-chain fatty acids or whether incoming fatty acids are directed to either the mitochondrial or microsomal enzyme, depending on the physiological state. As the inner mitochondrial membrane is impermeable to CoA and acyl-CoA, a specific transport system is required for the transfer of long-chain acyl-CoA into the mitochondria for oxidation. This transfer involves the sequential action of two carnitine acyltransferases (see Bremer, 1983). Carnitine acyltransferase I (CAT I), located on the outer side of the inner mitochondrial membrane, catalyzes the synthesis of acylcarnitine esters which are then translocated through the inner membrane into the matrix of the mitochondria by carnitine-acylcarnitine translocase (fig. 1). Carnitine acyltransferase II (CAT II), located on the inside surface of the inner mitochondrial membrane, transforms acylcarnitine esters into the corresponding long-chain acyl-CoA which is oxidized in two stages by specific enzymes located in the mitochondrial matrix. In the first stage, acyl-CoA undergoes $\beta$-oxidation which generates acetyl-CoA and reduced equivalents (NADH and $\mathrm{FADH}_{2}$ ). In the second stage, acetyl-CoA is oxidized via the citric acid cycle to yield $\mathrm{CO}_{2}, \mathrm{H}_{2} \mathrm{O}, \mathrm{GTP}$ and further reduced equivalents. These reduced equivalents may enter the respiratory chain to yield ATP (fig. 1).

In contrast to long-chain fatty acids, short or medium-chain fatty acids (chain length of less than 10 carbons) readily traverse the mitochondrial membranes and are activated to their corresponding acyl-CoA by a short or medium-chain acylCoA synthetase located in the mitochondrial matrix. Short and medium-chain acyl-CoA then undergo $\beta$-oxidation as do long-chain acyl-CoA. The metabolic fate of acyl-CoA in mitochondria is different in liver than in extra-hepatic tissues. In the mitochondria of heart, skeletal muscles and kidney cortex the final products of fatty acid oxidation are $\mathrm{CO}_{2}, \mathrm{H}_{2} \mathrm{O}$ and ATP ; in the mitochondria of liver a part of the acetyl-CoA produced by $\beta$-oxidation is used for ketone body synthesis (fig. 1). These ketone bodies are then released into the circulation and carried to the extra-hepatic tissues where they are completely oxidized (see Robinson and Williamson, 1980 ; Williamson, 1982).

It has been demonstrated recently that fatty acid oxidation can also occur in peroxisomes (Lazarow and De Duve, 1976). However, there are several important differences between the mitochondrial and peroxisomal pathways : (1) the first enzyme of peroxisomal $\beta$-oxidation is an acyl-CoA oxidase that transfers electrons directly to $\mathrm{O}_{2}$ and generates $\mathrm{H}_{2} \mathrm{O}_{2}$; (2) peroxisomes do not completely oxidize acyl-CoA to acetyl-CoA ; acyl-CoA shorter than octanoyl-CoA are not oxidized and are exported out of the peroxisomes into the mitochondria for oxidation ; $(3)$ peroxisomal fatty acid oxidation is not coupled to the respiratory chain ; (4) carnitine is not required for the transport of long-chain acyl-CoA across the peroxisomal membrane (see Debeer and Mannaerts, 1983). The experimental evidence presently available indicates that peroxisomal $\beta$-oxidation plays a minor role in overall fatty acid oxidation in both adult (Debeer and Mannaerts, 1983) and 
newborn (Krahling et al., 1979; Horie, Ishii and Suga, 1981) rats. Only mitochondrial fatty acid oxidation will be discussed in the following paragraphs.

Several factors may be involved in the development of fatty acid oxidation in individual tissues : (1) the supply of fatty acids and carnitine, (2) the activity and amounts of various enzymes of fatty acid oxidation and ketogenesis and (3) the presence or absence of specific cofactors or hormones involved in the regulation of these metabolic pathways. The aim of the present paper is to review the changes in fatty acid oxidation that occur in mammals at two crucial steps in their development, i.e. during fetal-neonatal transition and during suckling-weanling transition. Several reviews on this subject have been published previously (Bailey and Lockwood, 1973 ; Warshaw, 1979 ; Williamson, 1982).

\section{A. Supply of fatty acid and carnitine during development.}

The fetus of most mammals is devoid of adipose tissue at term (see Girard and Ferré, 1982), and the NEFA present in fetal plasma are derived from the maternal circulation. The facility with which NEFA cross the placenta varies considerably from one species to another. It occurs currently in those species with sizeable lipid stores at birth, e.g. humans, guinea-pigs and rabbits, but not in those with limited lipid stores, e.g. sheep, pigs and rats (see Girard and Ferré, 1982). Carnitine is a necessary cofactor in the optimal transfer of long-chain fatty acids across the mitochondrial membranes and hence could play an essential role in regulating fatty acid oxidation and ketone body formation. In both the liver and kidney of adults, carnitine is synthesized from the essential amino acids, lysine and methionine (see Bremer, 1983). Since the fetus has a very limited ability to synthesize carnitine (Hahn, 1981), it is entirely dependent upon the placental transfer of maternally-derived carnitine. In rats and sheep the placental transfer of carnitine is poor (Hahn and Skala, 1975 ; Hahn et al., 1977), as is the transport of NEFA, and it is not surprising that fatty acids do not contribute significantly to fetal oxidative metabolism (Battaglia and Meschia, 1978; Girard, Pintado and Ferré, 1979 ; Girard and Ferré, 1982). In rabbits and guinea-pigs the placental transfer of both carnitine (Hahn, Seccombe and Towell, 1981) and NEFA is rapid but, despite an adequate supply of these, the fetal tissues do not oxidize fatty acids. The reasons for this will be discussed below.

Immediately after birth and throughout the suckling period newborn mammals are fed with milk which, in most species, is a high-fat, lowcarbohydrate diet (Jenness, 1974). More than $90 \%$ of milk fat is in the form of triglycerides and, in many species, they contain significant amounts of mediumchain fatty acids (Dils and Parker, 1982). Whereas long-chain fatty acids are absorbed from the small intestine as chylomicrons, medium-chain fatty acids are absorbed from the stomach as free acids (Hamosh, 1979 ; Fernando-Warnakulasuriya et al., 1981 ; Aw and Grigor, 1980) and, as such, are excellent oxidative substrates for neonatal tissues, particularly for the liver (Frost and Wells, 1981). In rats, a large rise in plasma NEFA and triglyceride occurs a few hours after birth with the onset of suckling, and plasma NEFA and triglyceride levels 
remain very high throughout the suckling period, decreasing after weaning (Page, Krebs and Williamson, 1971 ; Dahlquist, Persson and Persson, 1972 ; Foster and Bailey, 1976a ; Planche et al., 1980). The capacity of extra-hepatic tissue to take up plasma triglycerides increases during the suckling period in rats. The lipoprotein lipase activity of heart, skeletal muscles and brown adipose tissue (BAT) emerges substantially during the first $24 \mathrm{~h}$ after birth (Cryer and Jones, 1978) and remains elevated during the suckling period (Cryer and Jones, 1978 ; Planche et al., 1980). The NEFA released by the hydrolysis of plasma triglycerides are thus directly available as fuel for the extra-hepatic tissues. After birth, carnitine concentration increases markedly in heart, skeletal muscles, BAT and liver with the onset of suckling (Robles-Valdes, McGarry and Foster, 1976; Borum, 1978 ; Hahn and Skala, 1972 ; Bieber et al., 1973 ; Carroll et al., 1983). As newborn rats have a low ability to synthesize carnitine during the first postnatal week (Hahn, 1981), it is synthesized in the liver of the lactating dams and then transferred to the pups via the milk (Robles-Valdes, McGarry and Foster, 1976). Thus, the supply of NEFA and carnitine to neonatal tissues is very high during the suckling period and can maintain the capacity for fatty acid oxidation at a high level.

The transition from milk to chow is gradual in laboratory animals, and weaning is characterized by a change from a high-fat/low-carbohydrate diet to a high-carbohydrate/low-fat diet (Henning, 1981). The intestine progressively becomes the more important site of dietary fat absorption and digestion when pancreatic lipase appears, long-chain fatty acids being absorbed via the lymphatic ducts as chylomicrons, as in adults, (Hamosh, 1979; Henning, 1981). Weaning in rats is associated with a decrease in plasma NEFA and triglyceride levels (Foster and Bailey, 1976a). After weaning, lipoprotein lipase activity remains high in heart but decreases markedly in skeletal muscles and BAT (Cryer and Jones, 1978). In contrast, kidney lipoprotein lipase activity, which is low during the suckling period, increases to reach adult values one week after weaning (Planche et al., 1980). Thus, the suckling-weaning transition is characterized by a decrease in the supply of fatty acid to the tissue of fed young and adult rats.

\section{B. Development of fatty acid oxidation in extra-hepatic tissues.}

In vitro studies using tissue homogenates (Warshaw, 1972; Glatz and Veerkamp, 1982 ; Wolfe, Maxwell and Nelson, 1978), isolated mitochondria (Warshaw and Terry, 1970 ; Werner et al., 1982) or isolated perfused organ (Werner et al., 1983b) have shown that the heart of fetal rats, rabbits, pigs and calves has a very low capacity for long-chain fatty acid oxidation, even in the presence of carnitine. Similarly, compared to adults, the rate of palmitate oxidation is reduced in skeletal muscle homogenates (Glatz and Veerkamp, 1982 ; Carroll et al., 1983 ; Wolfe. Maxwell and Nelson, 1978 ; Mac Larty et al., 1984) and in kidney slices (Wolfe, Maxwell and Nelson, 1978; Freund, Sedraoui and Geloso, 1984), lung (Warshaw, Terry and Ranis, 1980) and small intestine (Warshaw, 1974) of fetal rats and pigs. As the rate of oxidation of octanoate, 
octanoylcarnitine or palmitoylcarnitine is similar in the heart of fetal, newborn and adult pigs and calves (Werner et al., 1983a, b ; Warshaw and Terry, 1970), it has been suggested that the reduced capacity of the fetal tissues to oxidize long-chain fatty acids could result from the low activity of carnitine acyltransferase I (Warshaw, 1972 ; Carroll et al., 1983 ; Delaval et al., 1984). Moreover, a reduced number of mitochondria in fetal tissues could also be responsible for their low capacity to oxidize NEFA (Warshaw, 1972 ; Glatz and Veerkamp, 1982 ; Barrie and Harris, 1977).

The capacity of heart (Wittels and Bressler, 1965; Warshaw and Terry, 1970 ; Warshaw, 1972 ; Mersmann and Phinney, 1973 ; Aprille, 1976 ; Wolfe, Maxwell and Nelson, 1978 ; Werner et al., 1982, 1983a), skeletal muscle (Wolfe, Maxwell and Nelson, 1978 ; Glatz and Veerkamp, 1982 ; Carroll et al., 1983) and kidney (Wolfe, Maxwell and Nelson, 1978 ; Freund, Sedraoui and Geloso, 1984) to oxidize NEFA increases shortly after birth in rats, rabbits, pigs and calves. In contrast, it has been reported that substantial fatty acid oxidation occurs only 2 weeks after birth in dog heart (Breuer et al., 1968). Rosenthal and Warshaw (1977) have reported that fatty acid oxidation remains very low in heart cells isolated from 15-day old fetal rats and cultured for a period of time (6-12 days) which spans the expected perinatal rise in fatty acid oxidation. This provides indirect evidence that birth-associated changes are regulated and are not the result of a predetermined program. It also seems that the transition to a high-fat diet is not a prerequisite for the increased ability to oxidize fatty acid in neonatal tissues. Indeed, young rabbits or piglets maintained on low-fat diets develop a normal capacity to oxidize fatty acids in heart, skeletal muscle and kidney (Aprille, 1976 ; Wolfe, Maxwell and Nelson, 1978).

In general, the rise in the capacity of the extra-hepatic tissues to oxidize fatty acids varies in parallel with CAT activity. A rise in this activity occurs immediately after birth in the heart (Wittels and Bressler, 1965; Warshaw, 1972 ; Lockwood and Bailey, 1970 ; Barrie and Harris, 1977), skeletal muscle (Carroll et al., 1983), lung (Warshaw, Terry and Ranis, 1980) and kidney (Delaval et al., 1984) of rats and remains elevated throughout the suckling period. However, CAT activity does not change with age in the heart, leg muscles and kidney of pigs, although palmitate oxidation increases 2 to 3-fold (Wolfe, Maxwell and Nelson, 1978). The increase in the number of mitochondria that occurs after birth in the extra-hepatic tissues (Warshaw, 1972 ; Barrie and Harris, 1977 ; Glatz and Veerkamp, 1982) is obviously a factor in the increased capacity for fatty acid oxidation.

After weaning, this capacity remains elevated in heart (Warshaw, 1972 ; Glatz and Veerkamp, 1982 ; Werner et al., 1982), kidney (Novakova et al., 1980 ; Freund, Sedraoui and Geloso, 1984) and, to a lesser extent, in skeletal muscles (Glatz and Veerkamp, 1982 ; Carroll et al., 1983). This is not surprising since it is well known that NEFA are the preferred fuel of adult heart, kidney and resting muscles (see review by Owen and Reichard, 1974).

\section{Development of fatty acid oxidation and ketogenesis in the liver.}

A number of mechanisms have been proposed to explain the increased rate of fatty acid oxidation and ketogenesis in adult rats during starvation and diabetes 
(McGarry and Foster, 1980). These include increased delivery of fatty acids to the liver, an enhanced plasma glucagon : insulin ratio, a rise in hepatic carnitine level, and $a$ fall in liver malonyl-CoA (the first committed intermediate in hepatic lipogenesis which is a powerful inhibitor of CAT I) that initiates the carnitine acyltransferase reaction (McGarry and Foster, 1980). These different factors and their involvement in the development and regulation of hepatic fatty acid oxidation and ketogenesis will be considered in the following discussion.

\section{Fetal-neonatal transition.}

a) Increased fatty acid availability. - During the neonatal period, the NEFA supplied to the liver originate from two different sources : (1) triglycerides stored in white adipose tissue or liver and (2) milk triglycerides. The importance of endogenous triglycerides as ketone body precursors can be studied in starved newborns. Newborn guinea-pigs and rabbits which have very little white adipose tissue and large fat stores in the liver develop a marked hyperketonemia after 12-24 h, if they are not fed from birth (Callikan et al., 1979 ; Duée et al., 1983). In these species, NEFA provided by hepatic triglyceride breakdown are the major precursors of ketone bodies during starvation. In keeping with this, it has been shown that several drugs which inhibit lysosomal acid triglyceride lipase completely suppress the endogenous production of ketone bodies by isolated hepatocytes from starved newborn rabbits (Duée et al., 1985).

Newborn human babies which are endowed with significant fat stores in both the liver and white adipose tissue also show an increase in blood ketone body levels when they are starved from birth (Melichar, Drahota and Hahn, 1965 ; Haymond, Karl and Pagliara, 1974); the NEFA used for ketone body production are derived from both the adipose tissue and the liver.

In contrast, newborn rats which have no fat stores at birth remain hypoketonemic if they are starved from birth (Girard et al., 1973). Thus, efficient ketogenesis in these animals appears to be entirely dependent upon NEFA provided by hydrolysis of milk triglycerides (Ferré et al., 1978). In suckling rats blood ketone body concentrations increase slowly during the first $12 \mathrm{~h}$ after birth, despite the large increase in plasma NEFA which occurs $2 \mathrm{~h}$ after birth. Blood ketone bodies then increase sharply between 12 and $16 \mathrm{~h}$ without any further rise in plasma NEFA levels (Ferré et al,, 1978). A similar pattern in the ketogenic capacity of newborn rats is observed when starved newborns are fed with a triglyceride emulsion containing long-chain fatty acids (Ferré et al., 1978) or medium-chain fatty acids (unpublished data) at different times after birth. This suggests that factors other than NEFA availability alone are responsible for the onset of ketogenesis in newborn rats (Ferré et al., 1978). Similarly, a delay of 6 to $12 \mathrm{~h}$ in the appearance of hyperketonemia has been observed in suckling rabbits (Girard and Ferré, 1982), guinea-pigs (Duée et al., 1983) and breast-fed human babies (Melichar, Drahota and Hahn, 1965 ; Persson and Gentz, 1966 ; Warshaw and Curry, 1980).

In suckling lambs, pigs and dogs (Varnam, Jeacock and Shepherd, 1978 ; Bengtsson et al., 1969 ; Gentz et al., 1970 ; Pégorier et al., 1981 ; Spitzer and Weng, 1972), blood ketone body levels remain very low despite high plasma 
NEFA concentrations. The reasons for these species differences are not well understood, but recent experiments on isolated hepatocytes from newborn pigs have shown that $80-85 \%$ of the fatty acids taken up are converted into esterified fats, thus markedly limiting fatty acid oxidation and ketogenesis (Pégorier et al., 1983). However, ketone bodies are unlikely to play a role as energy substrates in the newborn of these species.

b) Increased plasma glucagon: insulin ratio. - During the immediate postnatal period there is a marked rise in plasma glucagon and a fall in plasma insulin in rats (Girard et al., 1973 ; Blazquez et al., 1974), rabbits (Callikan et al., 1979), and humans (Sperling et al., 1974). Similar changes occur in both fasted and suckled rat neonates (Girard et al., 1980), and high plasma glucagon and low plasma insulin prevail throughout the suckling period in rats (Blazquez et al., 1972 ; Beaudry, Chiasson and Exton, 1977 ; Girard et al., 1977). These hormonal changes are highly appropriate for the initiation and maintenance of efficient ketogenesis in the liver of newborns.

c) Intrahepatic regulation of ketogenesis in newborns. - Most of the information presently available on the development of hepatic ketogenesis has been obtained in rats. In vitro studies using liver homogenates (Augenfeld and Fritz, 1970 ; Lee and Fritz, 1971 ; Lockwood and Bailey, 1970 ; Foster and Bailey, 1976b ; Yeh and Zee, 1976, 1979; Yeh, Streuli and Zee, 1977 ; Chalk et al., 1983), liver slices (Drahota et al., 1964) and isolated hepatocytes (Ferré et al., 1983) have shown that the rates of long-chain fatty acid oxidation and ketone body production are very low in fetal rat liver and that they markedly increase in newborns from day 1 of age. These changes are accompanied by an increase in the activity of CAT I (Augenfeld and Fritz, 1970 ; Lockwood and Bailey, 1970 ; Warshaw, 1972 ; Foster and Bailey, 1976b; Yeh and Zee, 1979) and of the enzymes of the hydroxymethyl-glutaryl CoA (HMGCoA) pathway (Lockwood and Bailey, 1971 ; Lee and Fritz, 1971 ; Hipolito-Reis, Bailey and Bartley, 1974 ; Shah and Bailey, 1977). Unfortunately, these studies do not provide any information on the time-course or the possible factors regulating hepatic ketogenesis during the first $24 \mathrm{~h}$ of life, the period during which ketogenesis appears in the liver and reaches adult values. Recent experiments using newborn rat hepatocytes, isolated at different times after birth and incubated in the presence of equal concentrations of oleate or octanoate, show that ketogenic capacity increases with both substrates during the $16 \mathrm{~h}$ following birth (Girard et al., 1981 ; Ferré et al., 1983). However, octanoate is more ketogenic than oleate (fig. 2). These data confirm that factors other than NEFA availability are responsible for the onset of ketogenesis at birth, and they suggest that CAT I is not the only limiting factor.

Since liver carnitine concentration increases after birth in suckling rats it was suggested that carnitine is a key factor in triggering ketogenesis at birth (RoblesValdes, McGarry and Foster, 1976). Several lines of evidence indicate that this hypothesis may not be valid : (1) liver carnitine concentration increases $2 \mathrm{~h}$ after birth whereas maximal ketonemia is reached only at $12 \mathrm{~h}$ after birth (Ferré et al., 1978), (2) 16-hour old starved rats fed with triglyceride emulsion alone or supplemented with carnitine reach the same degree of hyperketonemia (Ferré et al., 1978), 

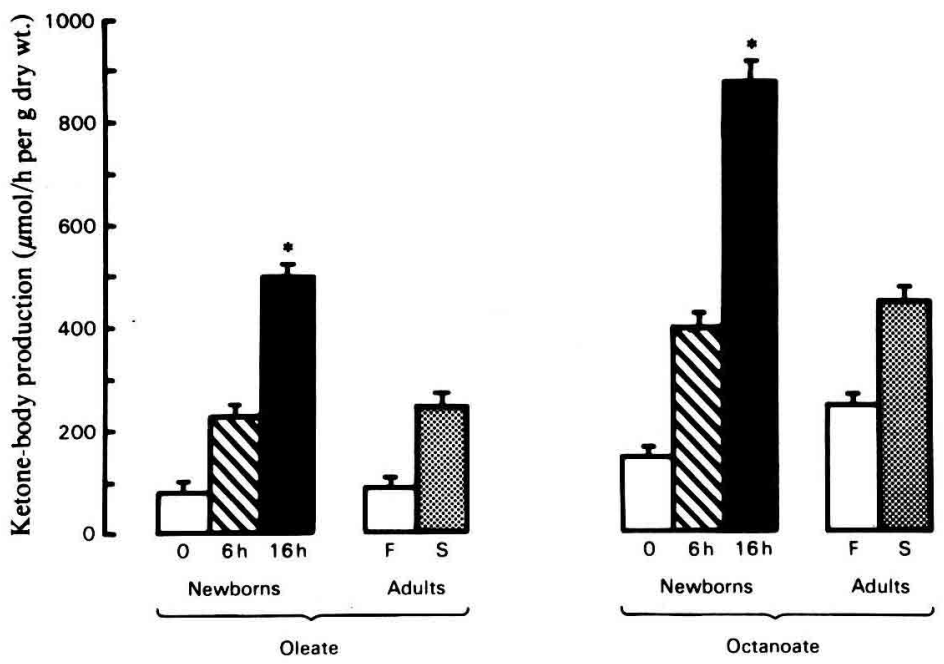

FIG. 2. - Ketogenesis from oleate and octanoate in isolated hepatocytes from newborn and aduit rats. Isolated hepatocytes from starved newborn rats and from fed (F) or 48-hour fasted (S) rats were incubated with $0.4 \mathrm{mM}$ oleate or $2 \mathrm{mM}$ octanoate. From Ferré et al. (1983).

and (3) ketogenesis from oleate is 6-fold higher at $16 \mathrm{~h}$ after birth than at delivery in hepatocytes isolated from newborn rats and incubated with carnitine (1 $\mathrm{mM})$ (Ferré et al., 1983).

Using $\left[1-{ }^{14} \mathrm{C}\right]$-oleate, it has been shown that the increase in ketone body production that occurs between birth and $16 \mathrm{~h}$ after delivery does not result from a fall in fatty acid esterification but is related to increased fatty acid oxidation (Ferré et al., 1983).

In adult rats it has been reported that malonyl-CoA, a key intermediate in the lipogenic pathway, inhibits fatty acid oxidation by decreasing the activity of CAT I (MCGarry, Mannaerts and Foster, 1977; McGarry, Takabayashi and Foster, 1978). As malonyl-CoA concentrations are directly related to the rate of lipogenesis, this implies that there is an inverse relationship between lipogenesis and ketogenesis. Moreover, in adult rats CAT I sensitivity to malonyl-CoA is decreased in ketogenic states and this might contribute to an increase in fatty acid oxidation (Cook, Otto and Cornell, 1980 ; Ontko and Johns, 1980 ; Bremer, 1981 ; Saggerson and Carpenter, 1981 ; Cook, Stephens and Harris, 1984). The rate of lipogenesis from ${ }^{3} \mathrm{H}_{2} \mathrm{O}$ is $60 \%$ lower in hepatocytes from newborn rats than in those from fed adult rats, and it decreases to undetectable values in 16-hour old starved newborns (fig. 3 ; Ferré et al., 1983). In addition, the sensitivity of CAT I to the inhibitory effect of malonyl-CoA decreases between 0 and $24 \mathrm{~h}$ after birth (fig. 4 ; Saggerson and Carpenter, 1982). Thus, it would seem that the onset of ketogenesis at birth could be related to a malonyl-CoA-dependent mechanism. However, the addition of glucagon and 5-tetradecyloxy-2-furoic acid (TOFA, an inhibitor of acetyl-CoA carboxylase) to hepatocytes from newborn rats $(0 \mathrm{~h})$ suppresses the rate of lipogenesis by $90 \%$, but without a simultaneous increase in fatty acid oxidation and ketogenesis

Reproduction Nutrition Développement, $\mathrm{n}^{\circ} 1$ B-1985. -11. 

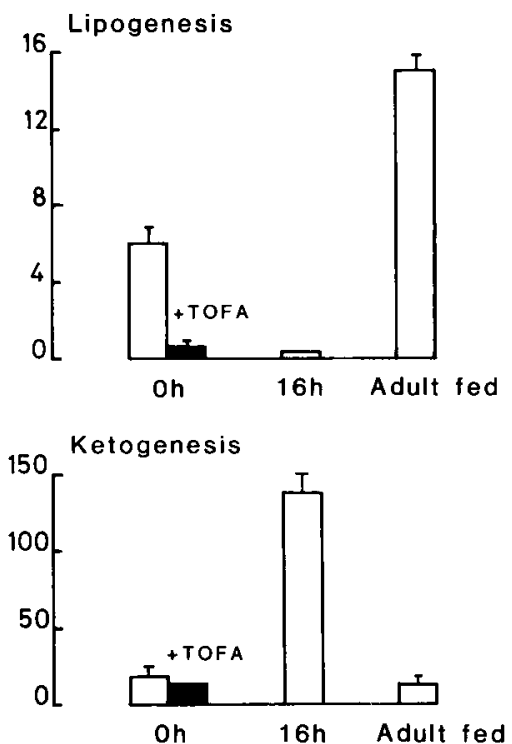

FIG. 3. - Lipogenesis from ${ }^{3} \mathrm{H}_{2} \mathrm{O}$ and ketogenesis from oleate in hepatocytes from newborn and fed adult rats. Isolated hepatocytes from 0 and 16-hour old starved newborn and fed adult rats were incubated with $0.4 \mathrm{mM}$ oleate, $10 \mathrm{mM}$ lactate and $1 \mathrm{mM}$ TOFA. From Ferré et al. (1983).

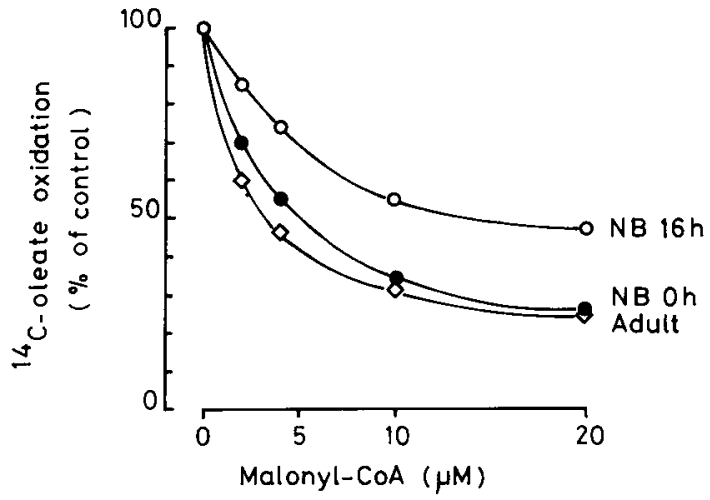

FIG. 4. - Effect of malonyl-CoA concentration on $\left[1^{14} \mathrm{C}\right]$-oleate oxidation by isolated mitochondria from $O$ and 16-hour old starved newborn and fed adult rats. The concentration of malonyl-CoA necessary to inhibit $50 \%$ of the oleate oxidation was : $6 \mu \mathrm{M}$ in 0 -hour old newborns, $14 \mu \mathrm{M}$ in 16hour old newborns and $3 \mu \mathrm{M}$ in adults (Escriva, Decaux, Ferré and Girard, unpublished data).

(fig. 3 ; Ferré et al., 1983). This suggests that malonyl-CoA is not the factor responsible for the switch-on of hepatic fatty acid oxidation and ketogenesis in newborn rats.

In newborn rats, octanoate oxidation is considered to be independent from the step catalysed by CAT I (Ferré et al., 1983). Ketone body production from octanoate increases 6-fold between 0 and $16 \mathrm{~h}$ after birth in hepatocytes from starved newborn rats (Ferré et al., 1983), indicating alterations in metabolic 
regulation at sites including octanoyl-CoA formation, $\beta$-oxidation and the HMGCoA pathway.

The capacity for $\beta$-oxidation and ketogenesis in guinea-pigs develops maximally during the first 6-12 $\mathrm{h}$ after birth (Shipp, Parameswaran and Arinze, 1982 ; Stanley, Gonzales and Baker, 1983). Studies using liver homogenates (Stanley, Gonzales and Baker, 1983) or isolated mitochondria (Shipp, Parameswaran and Arinze, 1982) suggest that ketone body synthesis in newly-born guinea-pigs is limited by three different factors : (1) the formation of acylcarnitine (CAT 1), (2) intramitochondrial capacity for $\beta$-oxidation and (3) the activation of medium-chain fatty acids.

\section{Suckling-weanling transition.}

In the suckling period, rat pups receive milk with a high-fat content and containing a high proportion of medium-chain fatty acids (Jenness, 1974). Physiological hyperketonemia occurs until the pups are weaned on to a commercial high-carbohydrate diet between 18 and 30 days after birth (Drahota et al., 1964 ; Page, Krebs and Williamson, 1971 ; Lockwood and Bailey, 1971 ; Dahlquist, Persson and Persson, 1972 ; Robles-Valdes, McGarry and Foster, 1976). Some of the enzymes concerned in fatty acid oxidation and ketogenesis show high activity during the suckling period but this activity declines to adult values at weaning (Foster and Bailey, 1976a ; Shah and Bailey, 1977). Particularly marked changes occur in CAT I activity which correlate well with the rate of palmitate conversion into ketone bodies by liver mitochondria (Foster and Bailey, $1976 \mathrm{~b})$. The rate of ketogenesis from endogenous substrates and from oleate in isolated hepatocytes from fed suckling rats decreases by 50 to $70 \%$ in the immediate post-weaning period (Benito, Whitelaw and Williamson, 1979 ; Decaux et al., 1985), whereas that from butyrate does not alter appreciably over this period (Benito, Whitelaw and Williamson, 1979). Moreover, the rate of hepatic lipogenesis, which is very low during the suckling period (Ballard and Hanson, 1967 ; Taylor, Bailey and Bartley, 1967 ; Lockwood, Bailey and Taylor, 1970 ; Benito, Whitelaw and Williamson, 1979 ; Sly and Walker, 1978), increases at the time of weaning. There is also a reciprocal relationship between ketogenesis and lipogenesis in isolated hepatocytes from weanling rats (Benito, Whitelaw and Williamson, 1979), indicating that, as in adult rats, the major site of ketogenic regulation during this period involves the distribution of long-chain fatty acyl-CoA between the pathways of esterification and $\beta$-oxidation. However, inhibiting the high rate of lipogenesis by TOFA in hepatocytes from weanling rats does not alter the rate of ketogenesis (Benito, Whitelaw and Williamson, 1979 ; Decaux et al., 1985). It may be that the mitochondrial capacity to oxidize fatty acids changes during the weaning period (see Decaux et al., 1985).

During this same period, a progressive decrease in plasma glucagon and a significant increase in plasma insulin are observed (Girard et al., 1977 ; Blazquez et al., 1972 ; Beaudry, Chiasson and Exton, 1977) concomitantly with a drop* in hepatic ketogenesis and a rise in hepatic lipogenesis. When rats are weaned prematurely to a high-fat diet, after 18 days of age, ketogenesis remains as high as it was during suckling (Decaux et al., 1985), whereas the rise in liver 
lipogenesis is prevented (Hahn and Kirby, 1973; Bailey and Lockwood, 1973 ; Decaux et al., 1985). In this case, plasma glucagon remains very high and plasma insulin very low (Girard et al., 1977), indicating that the rise in the plasma insulin : glucagon ratio could account for the shift in hepatic metabolism occurring during the weaning period.

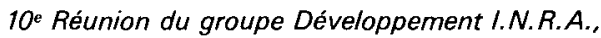
Rennes, 9-10 mai 1984.

Acknowledgements. - We wish to thank Dr. G. Crozier for reviewing this paper and Mrs I. Coquelet for preparing the manuscript. The personal work presented in this review was supported by INSERM (ATP grant $\mathrm{N}^{\circ}$ 79-106) and grants from "Ministère de I'Industrie et de la Recherche " (ATP 53-82 and 83-C-0448).

\section{Résumé. Oxydation des acides gras et cétogenèse au cours du développement.}

Les acides gras sont les substrats oxydatifs principaux du cœur, des muscles squelettiques, du cortex rénal et du foie chez les Mammifères adultes. Ils sont fournis à ces tissus soit sous la forme d'acides gras non-estérifiés soit sous la forme de triglycérides, après hydrolyse par la lipoprotéine lipase.

Pendant la vie fœtale, la capacité de ces différents tissus à oxyder les acides gras est très faible, même dans les espèces où le transfert placentaire d'acides gras et de carnitine s'effectue facilement. A la naissance, la capacité des différents tissus à oxyder les acides gras d'origine endogène ou fournis par les lipides du lait se développe rapidement et reste très élevée pendant la période d'allaitement. La capacité cétogénétique se développe dans le foie 6 à 12 heures après la naissance et les corps cétoniques servent de substrats oxydatifs à de nombreux tissus pendant toute la période de l'allaitement. Au moment du sevrage, le passage d'une alimentation lactée riche en lipides à I'alimentation du rat de laboratoire riche en glucides s'accompagne d'une diminution progressive des capacités cétogénétiques du foie alors que d'autres tissus (cœur, muscles, rein) conservent une capacité élevée d'oxyder les acides gras. Les facteurs nutritionnels et hormonaux impliqués dans les modifications des capacités d'oxydation des acides gras au cours du développement sont discutés dans cet article.

\section{References}

APRILLE J. R., 1976. Dietary lipid and postnatal development. II. Palmityl coenzyme A oxidation in heart and liver. Pediat. Res., 10, 982-985.

AUGENFELD J., FRITZ I. B., 1970. Carnitine palmitoyltransferase activity and fatty acid oxidation by livers from fetal and neonatal rats. Can. J. Biochem., 48, 288-294.

AW T. Y., GRIGOR M. R., 1980. Digestion and absorption of milk triacylglycerols in 14-day old suckling rats. J. Nutr., 110, 2133-2140.

BAILEY E., LOCKWOOD E. A., 1973. Some aspects of fatty acid oxidation and ketone body formation and utilization during development of the rat. Enzyme, 15, 239-253.

BALLARD F. J., HANSON R. W., 1967. Changes in lipid synthesis in rat liver during development. Biochem. J., 102, 952-958.

BARRIE S. E., HARRIS P., 1977. Myocardial enzyme activities in guinea pigs during development. Am. J. Physiol., 233, H707-H710.

BAtTAglia F. C., MeschIA G., 1978. Principal substrates of fetal metabolism. Physiol. Rev. 58, 499-527. 
BEAUDRY M. A., CHIASSON J. L., EXTON J. H., 1977. Gluconeogenesis in the suckling rat. Am. J. Physiol., 233, EI75-EI80.

BENGTSSON G., GENTZ J., HAKKARAINEN J., HELLSTROM R., PERSSON B., 1969. Plasma levels of FFA, glycerol, B-hydroxybutyrate and blood glucose during the postnatal development of the pig. J. Nutr., 97, 311-315.

BENITO M., WHITELAW E., WILLIAMSON D. H., 1979. Regulation of ketogenesis during the suckling-weanling transition in the rat. Studies with isolated hepatocytes. Biochem. J., 180, 137-144.

BIEBER L. L., MARKWELL M. A. K., BLAIR M., HELMRATH T. A., 1973. Studies on the development of carnitine palmitoyltransferase and fatty acid oxidation in liver mitochondria of neonatal pigs. Biochim. biophys. Acta, 326, 145-154.

BLAZQUEZ E., SUGASE T., BLAZQUEZ M., FOA P. P., 1972. The ontogeny of metabolic regulation in the rat, with special reference to the development of insular function. Acta diabetol. latina, 9, suppl. 1, 13-35.

BLAZQUEZ E. T., SUGASE T., BLAZQUEZ M., FOA P. P., 1974. Neonatal changes in the concentration of rat liver cyclic AMP and of serum glucose, FFA, insulin, pancreatic and total glucagon in man and in the rat. J. lab. c/in. Med., 83, 957-967.

BORUM P. R., 1978. Variation in tissue carnitine concentration with age and sex in the rat. Biochem. J., 176, 677-681.

BREMER J., 1981. The effect of fasting on the activity of liver carnitine paimitoyltransferase and its inhibition by malonyl CoA. Biochim. biophys. Acta, 665, 628-631.

BREMER J., 1983. Carnitine. Metabolism and functions. Physiol. Rev., 63, 1420-1480.

BREMER J., OSMUNDSEN H., 1984. Fatty acid oxidation and its regulation, 113-154. In S. NUMA, Fatty acid metabolism and its regulation. New comprehensive biochemistry, Vol. 7, Elsevier, Amsterdam.

BREUER E., BARTA F., ZLATOS L., PAPPOVA E., 1968. Developmental changes of myocardial metabolism. II. Myocardial metabolism of fatty acids in early postnatal period in dogs. Biol. Neonate, 12, 54-64.

CALLIKAN S., FERRÉ P., PÉGORIER J. P., MARLISS E. B., ASSAN R., GIRARD J., 1979. Fuel metabolism in starved newborn rabbits. J. develop. Physiol., 1, 267-281.

CARROLL J. E., SHUMATE J. B., VILLADIEGO A., CHOKSI R. M., MORSE D. P., 1983. Skeletal muscle fatty acid oxidation during early postnatal development in the rat. Biol. Neonate, 43 , 191-197.

CHALK P. A., HIGHAM F. C., CASWELL A. M., BAILEY E., 1983. Hepatic, mitochondrial fatty acid oxidation during the perinatal period in the rat. Int. J. Biochem., 15, 531-538.

COOK G. A., OTTO D. A., CORNELL N. W., 1980. Differential inhibition of ketogenesis by malonyl CoA in mitochondria from fed and starved rats. Biochem. J., 192, 955-958.

COOK G. A., STEPHENS T. W., HARRIS R. A., 1984. Altered sensitivity of carnitine palmitoyltransferase to inhibition by malonyl-CoA in ketonic diabetic rats. Biochem. J., 219, 337-339.

CRYER A., JONES H. M., 1978. Developmental changes in the activity of lipoprotein lipase (clearing factor lipase) in rat lung, cardiac muscle, skeletal muscle and brown adipose tissue. Biochem. J., 174, 447-451.

DAHLQUIST G., PERSSON U., PERSSON B., 1972. The activity of D-B hydroxybutyrate dehydrogenase in fetal, infant and adult rat brain and the influence of starvation. Biol. Neonate, 20. 40-50.

DEBEER L. J., MANNAERTS P., 1983. The mitochondrial and peroxisomal pathways of fatty acid oxidation in rat liver. Diabète \& Métabolisme. 9, 134-140.

DECAUX J. F., FERRE P., ROBIN P., ROBIN D., GIRARD J., 1985. Evolution du métabolisme hépatique des acides gras chez le rat au cours du sevrage. Reprod. Nutr. Dévelop., 25, in press.

DELAVAL E., ANDRIAMANANTSARA S., FREUND N., GELOSO J. P., 1984. Métabolisme rénal des acides gras au cours de la période périnatale chez le rat. Diabète $\&$ Métabolisme (sous presse).

DILS R. R., PARKER D. S., 1982. Metabolic aspects of lactation and the supply of nutrients to the young, 573-590. In C. T. JONES, Biochemical development of the fetus and neonate. Elsevier, Amsterdam. 
DRAHOTA Z., HAHN P., KLEINZELLER A., KOSTOLANSKA A., 1964. Acetoacetate formation by liver slices from adult and infant rats. Biochem. J., 93, 61-65.

DUÉE P. H., PÉGORIER J. P., BOIS-JOYEUX B., GIRARD J., 1983. Fuel metabolism and energy stores in fasting or suckling newborn guinea-pigs. J. Develop. Physiol., 5, 383-393.

DUÉE P. H., PÉGORIER J. P. KOHL C., GIRARD J., 1985. Development and regulation of ketogenesis in isolated hepatocytes from newborn rabbits. Reprod. Nutr. Dévelop., 25, in press.

FERNANDO-WARNAKULASURIYA G. J. P., STAGGERS J. E., FROST S. C., WELLS M. A., 1981. Studies on fat digestion, absorption and transport in the suckling rat. 1) Fatty acid composition and concentrations of major lipid components. J. Lipid Res., 22, 668-674.

FERRE P., PEGORIER J. P., WILLIAMSON D. H., GIRARD J. R., 1978. The development of ketogenesis at birth in the rat. Biochem. J., 176, 759-765.

FERRÉ P., SATABIN P., DECAUX J. F., ESCRIVA F., GIRARD J., 1983. Development and regulation of ketogenesis in hepatocytes isolated from newborn rats. Biochem. J., 214, 937 . 942.

FOSTER P. C., BAILEY E., 1976a. Changes in hepatic fatty acid degradation and blood lipid and ketone body content during development of the rat. Enzyme, 21, 397-407.

FOSTER P. C., BAILEY E., 1976b. Changes in the activities of the enzymes of hepatic fatty acid oxidation during development of the rat. Biochem. J., 154, 49-56.

FREUND N., SEDRAOUI M., GELOSO J. P., 1984. Fatty acid oxidation by developing rat kidney. Biol. Neonate, 45, 183-187.

FROST S. C., WELLS M. A., 1981. A comparison of the utilization of medium and long-chain fatty acids for oxidation and ketogenesis in the suckling rat : in vivo and in vitro studies. Arch. Biochem. Biophys., 211, 537-546.

GENTZ J., BENGTSSON G., HAKKARAINEN J., HELLSTROM R., PERSSON B., 1970. Metabolic effects of starvation during neonatal period in the piglet. Am. J. Physiol., 218, 662-668.

GIRARD J., FERRE P., 1982. Metabolic and hormonal changes around birth, 517-551. In C. T. JONES. Biochemical development of the fetus and the neonate, Elsevier, Amsterdam.

GIRARD J., PINTADO E., FERRE P., 1979. Fuel metabolism in the mammalian fetus. Ann. Biol. anim. Bioch. Biophys., 19, 181-197.

GIRARD J. R., CUENDET G. S., MARLISS E. B., KERVRAN A., RIEUTORT M., ASSAN R., 1973. Fuels, hormones and liver metabolism at term and during the early postnatal period in the rat. J. clin. Invest., 52, 3190-3200.

GIRARD J. R., FERRÉ P., KERVRAN A., PÉGORIER J. P., ASSAN R., 1977. Role of the insulin/glucagon ratio in the changes of hepatic metabolism during development of the rat, 563-581. In P. P. FOA, J. S. BAJAJ \& N. L. FOA, Glucagon: its role in physiology and clinical medicine, Springer Verlag, New York.

GIRARD J., FERRE P., PÉgORIER J. P., LETURQUe A., CALLIKAN S., 1980. Factors involved in the development of hypoglycemia in fasting newborn rats, 343-353. In D. ANDREANI, P. J. LEFEBVRE \& V. MARKS, Current views on hypoglycemia \& glucagon, Acad. Press, N.Y.

GIRARD J. R., FERRÉ P., EL MANOUBI L., PÉGORIER J. P., 1981. Ketone body metabolism during the neonatal period. Biochem. Soc. Transac., 9, 344-345.

GLATZ J. F. C., VEERKAMP J. H., 1982. Postnatal development of palmitate oxidation and mitochondrial enzyme activities in rat cardiac and skeletal muscle. Biochim. biophys. Acta, 711, 327-335.

HAHN P., 1981. The development of carnitine synthesis from butyrobetaine in the rat. Life Sci, 29, 1057-1060.

HAHN P., KIRBY L., 1973. Immediate and late effects of premature weaning and of feeding a highfat or high-carbohydrate diet to weanling rats. J. Nutr., 103, 690-696.

HAHN P., SKALA J., 1972. Carnitine and brown adipose tissue metabolism in the rat during development. Biochem. J., 127, 107-111.

HAHN P., SKALA J. P., 1975. The role of carnitine in brown adipose tissue of suckling rats. Comp. Biochem. Physiol., 51B, 507-515.

HAHN P., SKALA J. P., SECCOMBE D. W., FROHLICH J., PENN-WALKER D., NOWAK M., 
HYNIE E., TOWELL M. E., 1977. Carnitine content of blood and amniotic fluid. Pediat. Res., 11, 878-880.

HAHN P., SECCOMBE D. W., TOWELL M. E., 1981. The perinatal role of carnitine, 187-198. In M. MONSET-COUCHARD \& A. MINKOWSKI, Physiological and biochemical basis for perinatal medicine, Karger, Basel.

HAMOSH M., 1979. Fat digestion in the newborn : role of lingual lipase and preduodenal digestion. Pediat. Res., 13, 615-622.

HAYMOND M. W., KARL I., PAGLIARA A. S., 1974. Increased gluconeogenesis substrates in the small-for-gestational age infant. New England J. Med., 291, 322-328.

HENNING S. J., 1981. Postnatal development : coordination of feeding, digestion and metabolism. Am. J. Physiol., 241, G199-G214.

HIPOLITO-REIS C., BAILEY E., BARTLEY W., 1974. Factors involved in the control of the activity of enzymes of hepatic ketogenesis during development of the rat. Int. J. Biochem., 5, 31-39.

HORIE S., ISHII H., SUGA T., 1981. Developmental changes in the characteristics of peroxisomal fatty acid oxidation system in rat liver. Life Sci., 29, 1649-1656.

JENNESS R., 1974. Biosynthesis and composition of milk. J. Invest. Dermatol., 63, 109-118.

KRAHLING J. B., GEE R., GAUGER J. A., TOLBERT N. E., 1979. Postnatal development of peroxisomal and mitochondrial enzymes in rat liver. J. Cell Physiol., 101, 375-390.

KREBS H. A., 1972. Some aspects of the regulation of fuel supply in omnivorous animals. $A d v$. Enzyme Regul., 10, 397-420.

LAZAROW P. B., DE DUVE C., 1976. A fatty acyl-CoA oxidizing system in rat liver peroxisomes : enhancement by clofibrate, a hypolipidemic drug. Proc. nat. Acad. Sci., USA, 73, 2043-2046.

LEE L. P. K., FRITZ I. B., 1971. Hepatic ketogenesis during development. Can. J. Biochem., 49, 599-605.

LOCKWOOD E. A., BAILEY E., 1970. Fatty acid utilization during development of the rat. Biochem. J., 120, 49-54.

LOCKWOOD E. A., BAILEY E., 1971. The course of ketosis and the activity of key enzymes of ketogenesis and ketone body utilization during development of the postnatal rat. Biochem. J., 124, 249-254.

LOCKWOOD E. A., BAILEY E., TAYLOR C. B., 1970. Factors involved in changes in hepatic lipogenesis during development of the rat. Biochem. J., 118, 155-162.

Mac LARTY J. L., CAMPION D. R., HAUSMAN G. J., REAGAN J. O., MEREDITH F. I., 1984. Effect of fetal decapitation on the composition and metabolic characteristics of pig skeletal muscle. Biol. Neonate, 45, 142-149.

McGARRY J. D., FOSTER D. W., 1980. Regulation of hepatic fatty acid oxidation and ketone body production. Ann. Rev. Biochem., 49, 395-420.

McGARRY J. D., MANNAERTS G. P., FOSTER D. W., 1977. A possible role for malonyl-CoA in the regulation of hepatic fatty acid oxidation and ketogenesis. J. clin. Invest., 60, 265-270.

McGARRY J. D., TAKABAYASHI Y., FOSTER D. W., 1978. The role of malonyl-CoA in the coordination of fatty acid synthesis and oxidation in isolated rat hepatocytes. J. biol. Chem., 253, 8294-8300.

MELICHAR V., DRAHOTA Z., HAHN P., 1965. Changes in the blood levels of acetoacetate and ketone bodies in newborn infants. Biol. Neonate, 8, 348-352.

MERSMANN H. J., PHINNEY G., 1973. In vitro fatty acid oxidation in liver and heart from neonatal swine (Sus domesticus). Comp. Biochem. Physiol., 44B, 219-223.

NOVAKOVA J., CAPEK K., BASS A., TEISINGER J., VITEK V., POPP M., 1980. Postnatal changes of some enzymatic activities of energy supplying metabolism in the cortex, inner and outer medulla of the rat kidney. Physiol. Bohemos/ov., 29, 289-298.

OCKNER R. K., MANNING J. A., POPPENHAUSEN R. B., HO W. K. L., 1972. A binding protein for fatty acids in cytosol of intestinal mucosa, liver, myocardium and other tissues. Science, 177, 56-58.

ONTKO S. A., JOHNS M. L., 1980. Evaluation of malonyl-CoA in the regulation of long-chain fatty acid oxidation in the liver. Biochem. J., 192, 959-962.

OWEN O. E., REICHARD G. A. Jr., 1971. Fuels consumed by man : the interplay between carbohydrates and fatty acids. Prog. Biochem. Pharmacol., 6. 177-213. 
PAGE A., KREBS H. A., WILlIAMSON D. H., 1971. Activities of enzymes of ketone body utilization in brain and other tissues of suckling rats. Biochem. J., 121, 49-53.

PÉGORIER J. P., DUÉE P. H., ASSAN R., PERET J., GIRARD J., 1981. Changes in circulating fuels, pancreatic hormones and liver glycogen concentration in fasting or suckling newborn pigs. J. Develop. Physiol., 3, 203-217.

PÉGORIER J. P., DUÉE P. H., GIRARD J. R., PERET J., 1983. Metabolic fate of non-esterified fatty acids in isolated hepatocytes from newborn and young pigs : evidence for a limited capacity for oxidation and increased capacity for esterification. Biochem. J., 212, 93-97.

PERSSON B., GENTZ J., 1966. The pattern of blood lipids, glycerol and ketone bodies during the neonatal period, infancy and childhood. Acta paed. scand., 55, 353-362.

PLANCHE E., BOULANGE A., DE GASQUET P., TONNU N. T., 1980. Importance of muscle lipoprotein lipase in rats during suckling. Am. J. Physiol., 238, E511-E517.

ROBINSON A. M., WILLIAMSON D. H., 1980. Physiological roles of ketone bodies as substrates and signals in mammalian tissues. Physiol. Rev., 60, 143-187.

ROBINSON D. S., 1969. The function of plasma triglycerides in fatty acid transport. In M. FLORKIN \& E. H. STOTZ, Comprehensive biochemistry, Vol. 18, 51-104, Elsevier, Amsterdam.

ROBLES-VALDES C., McGARRY J. D., FOSTER D. W., 1976. Maternal fetal carnitine relationship and neonatal ketosis in the rat. J. biol. Chem., 251, 6007-6012.

ROSENTHAL M. D., WARSHAW J. B., 1977. Fatty acid and glucose oxidation by cultured rat heart cells. J. Cell Physiol., 93, 31-40.

SAGGERSON E. D., CARPENTER C. A., 1981. Effects of fasting, adrenalectomy and streptozotocindiabetes on sensitivity of hepatic carnitine acyltransferase to malonyl-CoA. FEBS Lett., 129. 225-228.

SAGGERSON E. D., CARPENTER C. A., 1982. Regulation of hepatic carnitine palmitoyl-transferase activity during the foetal-neonatal transition. FEBS Lett., 150, 177-180.

SHAH J., BAILEY E., 1977. Changes in the activities of the enzymes of hepatic ketogenesis in the rat between late fetal life and weaning. Enzyme, 22, 35-40.

SHIPP D. A., PARAMESWARAN M., ARINZE I. J., 1982. Development of fatty acid oxidation in neonatal guinea-pig liver. Biochem. J., 208, 723-730.

SLY M. R., WALKER D. G., 1978. A comparison of lipid metabolism in hepatocytes isolated from fed and starved neonatal and adult rats. Com. Biochem. Physiol., 61B, 501-506.

SPECTOR A. A., 1981. Metabolism of free fatty acids. Progr. Biochem. Pharmacol., 6, 130-176.

SPERLING M. A., DELAMATER P. V., PHELPS D., FISER R. H., OH W., FISHER D. A., 1974. Spontaneous and amino acid-stimulated glucagon secretion in the immediate postnatal period. J. clin. Invest., 53, 1159-1166.

SPITZER J. J., WENG J. T., 1972. Removal and utilization of ketone bodies by the brain of newborn puppies. J. Neurochem., 19, 2169-2173.

STANLEY C. A., GONZALES E., BAKER L., 1983. Development of hepatic fatty acid oxidation and ketogenesis in the newborn guinea-pig. Pediat. Res., 17, 224-229.

TAYLOR C. B., BAILEY E., BARTLEY W., 1967. Changes in hepatic lipogenesis during development of the rat. Biochem. J., 105, 717-722.

VARNAM G. C., JEACOCK M. K., SHEPHERD D. A., 1978. Hepatic ketone body metabolism in developing sheep and pregnant ewes. Brit. J. Nutr., 40, 359-367.

WARSHAW J. B., 1972. Cellular energy metabolism during fetal development. IV. Fatty acid activation, acyl transfer and fatty acid oxidation during development of the chick and rat. Develop. Biol., 28, 537-544.

WARSHAW J. B., 1974. Fatty acid oxidation during development, 88-97. In H. H. BODE, J. B. WARSHAW, Parenteral nutrition in infancy and childhood, Plenum Publ. Corp., N.Y.

WARSHAW J. B., 1979. Fatty acid metabolism during development. Seminars Perinatology, 3, 131-139.

WARSHAW J. B., CURRY E., 1980. Comparison of serum carnitine and ketone body concentrations in breast and in formula-fed newborn infants. J. Pediat., 97, 122-125.

WARSHAW J. B., TERRY M. L., 1970. Cellular energy metabolism during fetal development. II. Fatty acid oxidation by the developing heart. J. Cell Biol., 44, 354-360. 
WARSHAW J. B., TERRY M. L., RANIS M., 1980. Metabolic adaptation in developing lung. Pediatr. Res., 14, 296-299.

WERNER J. C., WHITMAN V., MUSSELMAN J., SCHULER H. G., 1982. Perinatal changes in mitochondrial respiration of the rabbit heart. Biol. Neonate, 42, 208-216.

WERNER J. C., WHITMAN V., VARY T. C., FRIPP R. R., MUSSELMAN J., SCHULER H. G., 1983a. Fatty acid and glucose utilization in isolated working newborn pig hearts. Am. J. Physiol., 244, E19-E23.

WERNER J. C., WHITMAN V., FRIPP R. R., SCHULER H. G., MUSSELMAN J., SHAM R. L., 1983b. Fatty acid and glucose utilization in isolated, working fetal pig hearts. $A m . J$. Physiol., 245, E19-E23.

WILLIAMSON D. H., 1982. The production and utilization of ketone bodies in the neonate, 621-650. In C. T. JONES, Biochemical development of the fetus and neonate, Elsevier, Amsterdam.

WITTELS B., BRESSLER R., 1965. Lipid metabolism in the newborn heart. J. clin. Invest., 44, 1639-1646.

WOLFE R. G., MAXWELL C. V., NELSON E. C., 1978. Effect of age and dietary fat level on fatty acid oxidation in the neonatal pig. J. Nutr., 108, 1621-1634.

YEH Y. Y., STREULI V. L., ZEE P., 1977. Relative utilization of fatty acids for synthesis of ketone bodies and complex lipids in the liver of developing rats. Lipids, 12, 367-374.

YEH Y. Y., ZEE P., 1976. Insulin : a possible regulator of ketosis in newborn and suckling rats. Pediatr. Res., 10, 192-197.

YEH Y. Y., ZEE P., 1979. Fatty acid oxidation in isolated rat liver mitochondria. Developmental changes and their relation to hepatic levels of carnitine and glycogen and to carnitine acyltransferase activity. Arch. Biochem. Biophys., 199, 560-569. 